\title{
Literatura, imprensa e mundo editorial: intermediações culturais na França da Terceira República*.
}

\author{
Literature, press and publishing world: cultural mediations in France \\ of the Third Republic.
}

\author{
Paulo Rodrigo Andrade Haiduke ${ }^{* *}$
}

\section{RESUMO}

Enfocando o ciclo romanesco do escritor Marcel Proust (1871-1922) intitulado A la recherche du temps perdu1 (publicado entre 1913 e 1927; no Brasil, intitulado Em busca do tempo perdido), a discussão aqui apresentada analisa algumas das relações que se estabeleceram entre literatura, imprensa e mercado editorial na França da Terceira República, mais especificamente em Paris nas décadas de 1910 e 1920. Através de fragmentos da realidade da cultura impressa, que foi um fato marcante desta conjuntura, a intenção central aqui é entender como a cultura midiática emergente atuou na difusão e sucesso da literatura modernista, como no caso da obra proustiana. Portanto, um dos pontos centrais desta reflexão é compreender o papel do novo intermediário cultural que se configurou então através da impressa e do mercado livresco, e que marcou de maneira fundamental a história do modernismo literário.

\section{ABSTRACT}

Focusing on the Marcel Proust's novel A la recherche du temps perdu (published between 1913 and 1927), the discussion presented here analyze some of the relationships that were established between literature, press and editorial market in France of the Third Republic, specifically in Paris in the 1910s and 1920s. Through reality fragments of print culture, which was a striking fact of this situation, the central intention here is to understand how the emergent mediatic culture served of the spread and success of modernist literature, as in the Proustian work. Therefore, one of the central points of this reflection is to understand the role of the new cultural intermediary who then set up through the printed and bookish market, and that marked a fundamental way the history of literary modernism.

Keyword: French Third Republic. Reception. Modernism. Marcel Proust. Literature critics.

\footnotetext{
* O presente artigo é parte de uma Tese de Doutorado defendida em 2013, e financiada pela Coordenação de Aperfeiçoamento de Pessoal de Nível Superior (Capes).

${ }^{* *}$ Universidade Estadual do Centro Oeste- Unicentro - e-mail: paulohaiduke@yahoo.com.br

1 A partir daqui citado apenas como Recherche.
} 


\section{Abertura e expansão do mundo editorial na Terceira República Francesa}

Em 1881, as novas leis republicanas na França possibilitaram, através da liberalização do mundo editorial, uma grande efervescência na vida literária. Segundo Gisèle Sapiro (2011, p. 329-330), desde então as casas de edição, livrarias, jornais e revistas ganharam uma grande liberdade de edição e publicação.

De fato, o recrudescimento da censura, somado às leis da mesma época em prol da ampla alfabetização, foram cruciais para as questões relativas à literatura ao longo da Terceira República². Para Leroy e Bertrand-Sabiani (1998, p. 2-3), estes fatores se somaram às questões conjunturais econômicas do capitalismo financeiro moderno que deram origem às grandes empresas editoriais já durante o Segundo Império. Neste sentido, a literatura teria entrado em uma nova época na qual o autor perdia a hegemonia do complexo processo de criação intelectual.

Christophe Charle (2004, p. 136), um dos principais especialistas sobre as relações entre história contemporânea e imprensa na França, salienta que a década de 1880 marcou uma grande expansão do mercado editorial. Para ele, isto derivou de quatro razões centrais: o aumento do leitorado, o progresso técnico, a abundância de capital econômico e a politização crescente do emergente público.

Esta nova situação de efervescência jornalística, literária e editorial em geral, marcada pelo consumo de massa, possibilitou e demandou novas estratégias por parte dos atores da vida literária, responsáveis não apenas pela produção dos textos, mas também pela sua distribuição e difusão. Muitos artistas, portanto, se deram conta da obsoleta noção de onipotência e poder pleno sobre suas obras, e assim puderam aproveitar modernas estratégias comerciais e publicitárias que levavam em consideração a espera do público e as formas pelas quais as obras literárias podiam ser aceitavelmente midiatizadas.

O mercado editorial se tornava cada vez mais relevante no final do século XIX, como principal veículo de disseminação da instrução na França republicana, engajada em erradicar o analfabetismo. Neste período, a taxa de analfabetos caíra para $5 \%$ da população, o que mostra o destaque da leitura como meio privilegiado do saber, e seu potencial para

2 A Terceira República foi instaurada na França ao longo da década de 1870, após a derrota na Guerra Franco -Prussiana e o fim do Segundo Império de Napoleão III. O regime republicano democrático durou algumas décadas, tendo findado em 1940 com a invasão alemã durante a Segunda Guerra Mundial. 
expandir a produção impressa. (LEROY; BERTRAND-SABIANI, 1998, p. 11). Porém, a liberalização do mundo editorial não se operou de maneira descontrolada, engajando diretamente seus agentes em responsabilidades, sobretudo para com os princípios de coesão nacional (SAPIRO, 2011, p. 323).

A responsabilidade como princípio guia gerou atenção social redobrada sobre a literatura, censura esta que buscava estabelecer aqueles que fossem imputáveis de culpa, como editores, redatores, autores, impressores, distribuidores ou vendedores. Neste sentido, a leitura, não era vista indiscriminadamente como algo positivo no final do século XIX e início do XX. Pois se por um lado se lia cada vez mais na França, por outro isto atiçava a inquietude dos moralistas e orientadores sociais, principalmente dos encarregados pela educação da juventude. Conforme Mollier (2008, p. 195): "a passagem da cultura erudita à cultura de massa amedronta as elites europeias desde os anos 1880.".

Este controle não era apenas uma censura realizada pelo Estado, mas permeava uma ampla e difusa rede de comentários e interpretações, além da própria publicidade, que buscava difundir sentidos e leituras supostamente legítimas das obras literárias. Conforme Luiz Costa Lima (1980, p. 101), os jornais passaram a exercer função decisiva na difusão das opiniões, e iniciação dos leitores, desde que houve uma ampla laicização da cultura. Porém, embora livre dos códigos morais estritamente religiosos, a imprensa não estava liberada para ser imoral ou amoral, sendo repetidas vezes conclamada e impelida a fomentar a moral da nação francesa.

Segundo Mollier (2008, p. 175-176), as décadas da chamada Belle Époque francesa, entre 1890 e a eclosão da guerra em 1914, marcaram de fato o surgimento do que podemos denominar de cultura midiática, fruto de uma revolução silenciosa que foi crucial para o grande sucesso da literatura. A extrema expansão então do mundo editorial estaria ligada a uma sociedade que rendia culto ao saber, e que ainda acreditava no pleno progresso pela expansão científica, e o controle da natureza. Vemos que, em detrimento das concepções decadentistas fin-de-siècle, havia ainda certo domínio das escolas ditas positivista e metódica, que seriam criticadas com mais força apenas pelas gerações pós-Grande Guerra (MOLLIER, 2008, p. 136-147).

De fato, conforme afirma Marie-Ėve Thérenty (2007, p. 124), as décadas de 1880-90 marcam a instalação de um novo regime de informação, que valorizava a escrita intimista. $O$ imperativo da imprensa na época, que privilegiava o fato visto ou ouvido, reforçou a importância de um sujeito encarregado da percepção e enunciação. O próprio sucesso crescente do formato da reportagem acabava por reafirmar o poder da subjetividade do jornalista como autor. Portanto, vemos que a ascensão da escrita inti mista coincidiu com o jornalismo de informação, indicando assim uma nova tendência: a aproximação entre escrita íntima, jornalismo e vida privada. 


\section{Era do material impresso}

Segundo Leroy e Bertrand-Sabiani (1998, p. 10), a Belle Époque francesa marcou uma profunda mudança na vida literária, quando as sedes de jornais, revistas e casas de edição tornaram-se os principais centros da vida literária, o que faz da imprensa e dos periódicos uma documentação crucial para estudar a sociedade e cultura da época. Conforme François Chaubet (2006, p. 727), com o passar dos anos o início do século XX vivenciou a elevação das revistas e casas de edição como novos e importantes locais de sociabilidade, em detrimento dos cafés e salões. Este foi, de fato, um período de efervescência editorial, ao longo do qual foram criados e encerrados diversos periódicos em toda França, sobretudo em Paris.

Conforme Christophe Charle (2004, p. 14), o impacto da imprensa foi tão grande, que elevou o jornal à posição privilegiada na relação entre homem e mundo exterior, exatamente pela sua função central de mídia. O Caso Dreyfus é considerado um marco para esta nova posição da imprensa durante a Terceira República: "As décadas de 1880/90 viram a imprensa substituir o parlamento como principal lugar e instrumento do debate público." (WEBER, 1989, p. 290-291).

Dados apresentados por Christophe Charle (2004, p. 136-137) expressam um aumento substancial no número de exemplares de jornais cotidianos impressos na época em Paris: de cerca de um milhão de exemplares na década de 1870 para extraordinários cinco milhões em 1910. O que significava metade dos 10 milhões de exemplares publicados em toda França, e demonstra o grande alcance desta mídia na população adulta, estimada em cerca de 20 milhões.

Este período entre a derrota na Guerra Franco-Prussiana e a Grande Guerra fomentou não apenas o crescimento dos periódicos, mas também do mercado editorial francês como um todo. Como nos mostra Jean-Yves Mollier (2008, p. 129-139), no final do século XIX se consolidou a publicação em larga escala de material impresso, sendo que os manuais, dicionários e enciclopédias dominaram então o mercado livresco.

Outro ramo do mercado editorial que cresceu muito então, e também viveu sua era de ouro durante a Terceira República, foi o das revistas e outros periódicos com uma periodicidade não necessariamente diária. Segundo Christophe Charle (2004, p. 169), em 1897 o número total de títulos destes periódicos chegara a seis mil em toda França. Esta grande diversidade respondia aos diversificados e modernos gostos e demandas da sociedade da época, que vivia constantes e incertas mutações. 
É interessante notar que a principal revista fin-de-siècle era a Revue des deux Mondes. Contudo, no início do século XX, este periódico acabou perdendo espaço significativo, em parte como consequência de seu endurecimento conservador e ataque à suposta decadência da cultura francesa resultante das vanguardas modernistas. Em 1893, Ferdinand Brunetière assumiu a direção da revista, dando-lhe uma tendência católica e conservadora (KARAKATSOULIS, 2009, p. 1188-1189). A perda substancial de assinantes desta revista no início do século (de $25 \mathrm{mil}$ em 1885 para $12 \mathrm{mil}$ em 1914, CHARLE, 2004, p. 170-171) mostra assim inversamente este período imediatamente anterior à guerra como conjuntura de grandes possibilidades de difusão pública para o modernismo.

Jornais, revistas e outros tipos de periódicos, informando, criticando ou elogiando, foram espaços cruciais para que pretendentes à literatura como Marcel Proust se construíssem como escritores durante este momento ímpar da mídia impressa que foi a Belle Époque da Terceira República. Nos anos precedentes à Grande Guerra, crescia o prestigio da então pequena revista, a Mercure de France, fundada em 1889 por um grupo de jovens escritores. Esta revista buscava se colocar como espaço da vanguarda literária, e de fato funcionou como uma das grandes mídias difusoras do simbolismo literário. Segundo Séverine Nikel (2009, p. 945-946), a abertura vanguardista deste periódico o tornou um dos mais influentes da cena literária francesa anterior à Guerra.

Esta experiência da Mercure de France foi um grande exemplo para aquela que viria a ser o grande sucesso entre as revistas literárias francesas do século $\mathrm{XX}$, a Nouvelle Revue Française. ${ }^{3}$ Em 1894, a Mercure de France fundou uma casa de edição, fortalecendo assim sua posição no mundo da imprensa e no mercado editorial. Conforme Charle (2004, p. 179), mesmo ideologicamente alinhada com uma posição desinteressada do mercado e não conformista, a Mercure de France acabou por assumir diversas características de uma grande revista.

A fundação da $N R F$ em 1909, apenas quatro anos antes do lançamento do primeiro volume da Recherche, evidencia ambos como eventos literários extremamente próximos e interligados, mesmo que Du côté de chez Swann tenha sido publicado originalmente por Bernard Grasset. Segundo Michel Winock (2002, p. 156): “A NRF estava apenas começando, ainda não dominava, mas já reivindicava em alto e bom som a autonomia da literatura ante as considerações políticas, morais e religiosas.”. É claro que esta reivindicação advinha do papel de destaque dos intelectuais e artistas dentro desta conjuntura, e assim o reforçava.

Portanto, o período anterior à Grande Guerra foi também uma espécie de Belle Époque para a imprensa e o mercado editorial, momento de grande crescimento na tiragem de jornais cotidianos, revistas periódicas e exemplares de livros. Embora mantendo relações estreitas, havia uma diferença importantíssima entre as duas principais mídias que

3 Daqui por diante também citada como NRF. 
difundiam então a literatura e o romance: a imprensa e o livro. Pois o livro era julgado como menos perigoso que a imprensa, embora de fato a fronteira entre ambos fosse extremamente nebulosa e incerta. Esta diferença da periculosidade advinha de uma concepção de públicos distintos, tanto culturalmente quanto quantitativamente. O que fazia dos periódicos, e principalmente do jornal, a mídia mais suspeita e perigosa na difusão de efeitos que fossem considerados prejudiciais à nação francesa, visto seu consumo de massa (SAPIRO, 2011, p. 422-423).

\section{Relações entre imprensa, mundo editorial e literatura}

Há inúmeros indícios das íntimas relações entre literatura, imprensa e mundo editorial nesta conjuntura que envolve a produção, e primeira publicação e recepção da Recherche. Estas trocas e tensões aconteceram de várias maneiras e em diversos níveis, e uma breve síntese da carreira literária de Proust pode ilustrar isto. Em sua juventude, ele se lançou em pequenas revistas literárias mais elitistas e defensoras do vanguardismo, publicou um livro restrito de textos literários curtos, além de publicar artigos sobre a vida mundana parisiense em jornais como Le Figaro. Mais tarde, publicou suas traduções de obras do esteta britânico John Ruskin, além escrever pastiches e outros textos de crítica literária. Somente então deu início à sua principal obra.

Vemos assim rapidamente pela trajetória literária de Proust como ele transitou, antes do sucesso, entre uma pretensa vanguarda literária das revistas da Belle Époque, a autoria de colunas sociais da mundanidade parisiense, o trabalho mais intelectual de tradução e comentário, além de uma atividade profícua dentro da crítica literária. Segundo Antoine Compagnon (1983, p. 17-18), Proust foi um dos últimos escritores para quem crítica ainda significava também literatura, não estando ainda legada exclusivamente ao estudo acadêmico. Isto ilustra a grande permeabilidade que existia entre estes mundos da imprensa e do mercado editorial, os privilegiados difusores da literatura.

Segundo Marie-Éve Thérenty (2007, p 115), durante as duas últimas décadas do século XIX, houve uma crescente voga de produção e demanda do público pelo romance sobre a atualidade, chamado de roman contemporaine. Segundo a autora, isto se deu por conta da demanda do público pelas questões da modernidade, das atualidades da realidade, o que aproximava muito este romance das próprias preocupações e escrita da imprensa.

Uma das críticas mais recorrentes à Recherche ao longo dos anos, sua suposta falta de plano prévio e premeditado de composição, é outro indício da intertextualidade da imprensa 
e da literatura na época. Jacquemaire demonstrou isto claramente em L'Echo National ${ }^{4}$ de 16 de março de 1924, ao comentar sobre o recém lançamento da continuação da Recherche com seu primeiro volume póstumo, La Prisonnière, editado e publicado pelo irmão do autor, Robert Proust, e o editor da $N R F$ e amigo de Proust, Jacques Rivière. O texto questiona se havia então algum mal entendido entre Proust e seus leitores, que teriam se sentido confusos com a leitura. A conclusão é que o problema advinha do fato que Proust não teria escrito um romance, como ele quis fazer crêr, mas sim algo que poderia ser chamado de Journal. Para Jacquemarie, isto resolveria todos os problemas levantados à obra, como composição, hipertrofia, digressões, pois aceita-se que na notação jornalística o autor se perca nos detalhes.

Segundo Jean-Yves Mollier (2008, p. 172), havia então um gosto público amplamente difundido pela estetização da vida cotidiana, fazendo com que a imprensa por sua vez fosse impregnada pela narrativa ficcional. Esta, por outro lado, utilizava não só as técnicas da imprensa, como seus temas para criar uma espécie de referencialidade dentro da obra e alcançar efeito de real nos leitores.

Para Leroy e Bertrand-Sabiani (1998, p. 13), a Belle Époque marcou uma ligação muito sólida entre a imprensa e a produção literária, visto a preocupação daquelas mídias em incorporar questões artísticas e literárias. Não é apenas porque os jornais tinham prazer em divulgar a literatura, mas porque a realidade da época estava de tal maneira impregnada e interessada pelas letras que isto se tornava uma questão da atualidade, de modernidade, que não podia ser negligenciada pelos órgãos da imprensa. De fato, mesmo jornais de grande tiragem voltados ao leitorado mais popular possuíam seus suplementos literários semanais. Segundo Marie-Ève Thérenty (2007, p. 90-120), a noção de atualidade era um dos principais elementos estruturantes da mídia periódica cotidiana. Nesta perspectiva, a questão de se dobrar ou não à atualidade significava a própria sobrevivência dos jornais e revistas. A autora destaca, porém, que o jornal cotidiano respondia por um lado à atualidade, mas também a construía, o que fazia desta atualidade uma realidade temporalmente circunscrita e culturalmente construída. Mas o fato é que, para as mídias periódicas, estar bem informado ou transmitir ao público esta sensação de conhecimento da contemporaneidade era neste contexto pressuposto do sucesso.

Thérenty destaca que ao longo do século XIX, a matriz midiática influenciou um campo muito mais amplo que o puramente jornalístico, com destaque à literatura ficcional. Os jornais franceses teriam se aberto assim para a produção de contos sobre a atualidade, valorizando um intenso diálogo entre a atualidade construída e difundida pelos jornais e a atualidade ficcionalizada pela literatura. Podemos assim concluir, com base nas análises

4 A partir daqui serão citados vários jornais e revistas, como L’Echo National (sempre em itálico), que formam o corpo documental central deste artigo. Optou-se aqui pela inserção do nome do periódico, do autor (quando não anônimo) e data no próprio corpo do texto como forma de referência para deixar a leitura mais fluída. As referências completas constam na bibliografia ao fim do artigo. 
desta autora, que o romance criava então seu efeito de real através de um acordo entre leitor e autor no que concernia a uma realidade textual midiática, que servia como base para a verossimilhança buscada Porém, devemos destacar que a influência aqui se fazia nos dois sentidos, levando jornais e revistas a adotarem códigos e regras habituais da literatura. Algumas técnicas literárias tornaram-se inclusive automatismos amplamente aplicados por jornalistas. A autora chega inclusive a afirmar que a ficcionalização foi o regime predominante da informação ao longo do século XIX na imprensa francesa, intertextualidade esta que teria não só perdurado, como se acentuado nas décadas da Belle Époque. (THÉRENTY, 2007, p. 90-120).

O aumento considerável no número do público leitor de jornais na França exigiu dos escritores um conhecimento mais profundo da realidade difundida pela imprensa, bem como de seus meandros e mecanismos. De fato, vemos pelo exemplo de Proust e de muitos outros escritores da época que gravitaram entre diversos periódicos e o mundo livresco que: "Grandes escritores da Belle Époque não sentiam acentuada aversão pelo impresso periódico” (MOLLIER, 2008, p. 161).

Para Mollier, havia então uma intensa troca entre os mundos do jornal e do livro, numa espécie de complementaridade entre o comentário sobre a atualidade e sua transcrição para a ficção:

Observa-se aqui, portanto, um duplo movimento que conduz os escritores a, ao mesmo tempo, fazer dos problemas de sua época um dos temas de seu universo ficcional e a utilizar a imprensa para interferir no debate político. Ora, é com as ferramentas da literatura que eles se transformam em jornalistas ou cronistas (MOLLIER, 2008, p. 163-164).

Ou seja, por maior que tenha sido a crítica na época à massificação da nova cultura midiática como símbolo do fim da literatura pura, houve na verdade uma troca incessante e duradoura entre ambos os mundos, isto em vários níveis.

O interesse pela atualidade ressaltado aqui, como objeto comum do jornalista, do crítico literário e do literato, tem para este último no mínimo dois sentidos: por um lado, a atualidade de sua obra, de seus métodos, seus estilos e técnicas, o que pode fazer da obra um novo capítulo dentro de uma história literária mais ampla; por outro lado, a atualidade mais visível e aparente do tema do romance, do seu objeto e assunto, ou seja, a atualidade de sua obra como representativa de questões importantes de uma época. 
Quando consideramos atentamente a atualidade literária como resultando de um fenômeno histórico e cultural, fica claro num contexto como a Belle Époque a importância da íntima ligação entre a crítica literária, a história da literatura e a imprensa em geral na formatação de parâmetros gerais e compartilhados.

Algumas das expressões mais interessantes desta ligação entre imprensa, literatura e atualidade são deflagradas pelos próprios títulos das colunas literárias das décadas de 191020 nos jornais e revistas parisienses, onde vemos claramente uma necessidade em apreender e difundir as principais características da então contemporaneidade literária: $A s$ direções atuais da literatura, As tendências presentes da literatura, A atualidade literária ${ }^{5}$, todas estas colunas buscavam de alguma maneira ilustrar aos leitores quais as novidades mais notórias e o que de fato seria relevante na modernidade literária.

Proust e sua obra tornaram-se objetos de constantes e acirrados debates sobre a sua soposta ou não modernidade neste entre guerras que, como nunca, vivenciou-se a ligação entre imprensa e edição (PARINET, 2004, p. 353). Como já vimos, ele chegou a ser considerado por alguns críticos literários inclusive como um dos principais acontecimentos literários da época, o que por si só já diz sobre sua atualidade.

Em dois artitos publicados no final de 1923 no periódico La vie des lettres et des arts, JeanCharles Grenier buscou compreender em que consistiria esta atualidade literária de Proust, um ano após a morte do escritor, quando seu mito parecia somente crescer. As hipóteses de Grenier inseriam a obra proustiana como encontro de diversas tendências da arte moderna, sobretudo o impressionismo e o simbolismo. Porém, a análise de Jean-Charles Grenier se torna mais interessante quando liga a criação proustiana à nova geração por um outro viés que não o literário, porém ainda mais moderno: haveria na obra proustiana um esforço tão contínuo em direção à exatidão dos retratos, que embora ainda impressionista e simbolista, apontava já para o cinema.

Podemos observar por este exemplo como a inserção de uma obra no rol das principais atualidades literárias de um dado momento podia ser extremamente importante para seu sucesso. Ser considerado a síntese literária de uma conjuntura, tal como Grenier interpreta a obra proustiana (um resumo das três décadas da história da literatura anteriores à 1923) não deve ser menosprezado como vetor de canonização.

Segundo Vanessa Schwartz (2001, p. 412), o advento do cinema no final do século XIX esteve intrinsecamente ligado ao crescente e generalizado interesse pela realidade. A autora destaca assim que este gosto por novas dimensões e aspectos do mundo se apoiava na imprensa de massa da época, fomentadora de uma cultura midiática que unia realismo, espetáculo e narrativa jornalística. Portanto, para que um debate literário e cultural 
ganhasse grandes e importantes dimensões, deveria ser de alguma maneira apreendido como questão extremamente pertinente da atualidade.

A ligação entre literatura e imprensa através da questão da atualidade, no caso de Proust, surge mais claramente logo após a concessão do Prix Goncourt no final de 1919, e ela adentra assim ao longo da década de 1920, com o lançamento dos sucessivos volumes da Recherche. E a presença de Proust nos debates literários foi se impondo de tal maneira que Daniel-Rops, na edição de junho de 1925 dos Cahiers du mois, afirmou categoricamente como passo indispensável para qualquer novato, jovem escritor ou crítico o engajamento na ardua ciência da exegese proustiana.

E de fato, em livros, jornais, revistas, cadernos e outros tipos de impressos, a exegese sobre Proust e sua obra era abundantemente produzida, chegando às centenas durante os anos de sua publicação, e sendo inclusive coroada com algumas edições especiais e coleções como, por exempo, os Cahiers Marcel Proust publicados a partir de 1928, e o Bulletin Marcel Proust publicado desde 1930.

\section{A importância das querelas na publicidade literária:Proust e o Prix Goncourt}

O Prix Goncourt de 1919 concedido ao segundo volume da Recherce, À l'ombre des jeunes filles en fleur, foi um acontecimento que interferiu crucialmente na recepção da obra, sendo que o debate gerado ocupou grande parte da imprensa parisiense. Estes prêmios literários tiveram, durante a Belle Époque, e no período pós-Grande Guerra, um papel muito importante na vida literária parisiense, e nos debates respectivos. Foram também espécies de ações na direção de uma busca de auto-regulação da literatura, de autonomização, como instâncias independentes de consagração. ${ }^{6}$ Embora existentes há alguns séculos, Anne Simonin afirma que foi somente no início do século XX que os prêmios literários se tornaram distinções cobiçadas. Data desta época, mais especificamente 1903, a criação do Prix Goncourt, que executava assim uma vontade do testamento dos escritores Edmond e Jules de Goncourt, e era destinado a encorajar as letras, sobretudo o romance (SIMONIN, 2009, p. 1132-1134).

6 Segundo Chaubet (2006, p. 726), o Prix Goncourt surgira da iniciativa de consolidar uma alternativa a oficial e tradicional Academia Francesa, visto que buscava consagrar a juventude e inovação. Por isso, o prêmio esteve inserido no seio da produção vanguardista. Sobre as questões referentes à autonomização do campo literário francês, ver Bourdieu (2005). 
A premiação de 10 de dezembro de 1919 foi permeada por muitas polêmicas e acusações, principalmente apontando o favorecimento que o presidente da Academia Goncourt, Léon Daudet, havia dado ao seu amigo e candidato preferido Marcel Proust. No jornal L'Opinion de 13 de dezembro de 1919, a notícia sobre a concessão do prêmio destacava como os escritores usavam seus amigos na imprensa, e criavam assim estreitos elos entre literatura e jornalismo.

Dois dias antes, o periódico Bonsoir destacava que aquele havia sido o Prix Goncourt mais polêmico até então. Independente do motivo atribuído pelo artigo, o fato é que estes prêmios se tornaram objetos de disputa cada vez mais desejados, na medida que surgiam como possibilidade de consagração literária.

Um dos principais argumentos feitos pelos acusadores do conluio entre os juízes do prêmio e o laureado, foi que Marcel Proust contava então com quase 50 anos de idade, algo incompatível com o desejo dos Goncourt, segundo o qual o prêmio deveria ser concedido a jovens promissores. Segundo Georges Clairet, em Le Journal du Peuple de 11 de dezembro de 1919, o vencedor do prêmio era não só muito velho e muito rico, como também produzira uma obra destituída de qualquer novidade e originalidade. Clairet afirma peremptoriamente que o editor de A l'ombre de Jeunes Filles en Fleurs, Gaston Gallimard, havia interferido na escolha, interpretando que foram as boas relações de Proust e da sua editora as verdadeiras causas pela vitória. Por fim, o autor conclui disto a própria posição política de Proust como um reacionário, não por ter sido supostamente beneficiado por homens alinhados à direita, como é o caso de Daudet, mas por ter se beneficiado de suas relações influentes, sobretudo dos chamados mundanos dos salões da alta sociedade parisiense.

Em 12 de dezembro, o jornal Le Pays publicou em sua primeira página uma notícia sobre o prêmio, acusando os membros da Academia Goncourt de estarem praticando política através da literatura, beneficiando Proust por ser candidato da ala reacionária. E conclui afirmndo que os membros do Prix Goncourt não aceitariam jamais coroar um dreyfusard, esquecendo que Marcel Proust foi assinante das primeiras petições em prol da revisão do processo do capitão Dreyfus.

J.-H. Rosny, um dos membros da Academia Goncourt, logo saiu em defesa do resultado proferido, e do laureado Proust, no jornal artístico Comoedia de 23 de dezembro. Segundo ele, materialmente Proust não tinha necessidade do prêmio pois era um homem abastado; porém, afirma Rosny, sua premiação era legítima como uma forma de compensação pelo pouco conhecimento de tal obra pelo público mais abrangente. Ou seja, ele justificou a premiação não pelo dinheiro em si, mas sim como forma de dar publicidade para um escritor que considerava importante e pouco conhecido.

Um dos principais argumentos contra a acusação da idade avançada de Proust foi a defesa de sua novidade como escritor e romancista. Muitos enfatizaram isto, como Paul 
Gsell em La Démocratie Nouvelle de 11 de dezembro de 1919, que relacionou juventude literária com desconhecimento. $\mathrm{O}$ comentador segue, porém, no mesmo sentido dos outros críticos, e afirma que a escolha para o prêmio não se deu exclusivamente por questões literárias, mas por Proust supostamente ser o candidato alinhado à direita, ao contrário do outro pretendente, Dorgelès.

Vemos, portanto, como os prêmios literários, recenseados em mais de vinte na França em 1924, eram extremamente importantes como meios de divulgação de obras, inclusive as posições e propostas modernistas. Observamos também como eram vinculados às questões e debates muito mais abrangentes que os puramente estéticos, como as questões da disputa entre esquerda e direita que aparecem nas fontes. Porém, conforme destaca Anne Simonin (2009, p. 1132-1134), a principal função dos prêmios literários era possibilitar a maior difusão e popularização da literatura, principalmente de vanguarda.

Retornando ao já citado e intrigante texto de Paul Gsell sobre a premiação em 1919, podemos ver que o autor afirma a completa inutilidade do prêmio, justamente por estar mais vinculado às relações externas à literatura. Porém, a visão de Gsell é um tanto idealista, e ignora a importância destes prêmios na divulgação de obras como o romance de Marcel Proust. De fato, até 1919, os volumes da Recherche e as outras produções de Proust publicados eram muito pouco conhecidos, estando mais restritos aos cenáculos de amigos e especialistas amantes e conhecedores da literatura. Contudo, a partir de 1919, e mais ainda após 1922 e a morte de Proust, a obra passou a ser amplamente comentada pela imprensa e crítica em geral. O fato é que tais prêmios eram extremamente importantes e cobiçados pelos escritores e editores pois, como afirma Albéric Cahuet na Illustration de 27 de dezembro de 1919, sem esta honra concedida pelos dez jurados da Academia Goncourt, a Recherche não seria de forma alguma apreciada para além de um pequeno grupo de pessoas. Portanto, vemos como um prêmio literário de prestígio podia muito bem funcionar como divulgador de obras modernistas, inovadoras e muitas vezes inacessíveis ao público mais amplo.

Tanto que, logo após a concessão do prêmio a Proust, o favorito derrotado Roland Dorgèles teve sua obra, Le Croix du Bois, envolvida em uma polêmica. Segundo Derive, em Comoedia de 3 de junho de 1920, o editor de Dorgèles havia sido processado por Gallimard, editor de Proust, por ter dado à entender que havia sido o livro do primeiro o vencedor do prêmio. Por fim, o editor de Dorgèles foi condenado a pagar indenização a Gallimard, além de retirar qualquer menção ao prêmio Goncourt do livro de Dorgèles e de toda sua publicidade.

Na edição em homenagem à Proust da Revue le Capitole de 1926, Gérard de Catalogne destacou com uma certa malícia que Marcel Proust teria tratado muito bem de sua publicidade. Segundo Catalogne, Proust soube mobilizar amigos que ajudaram e provaram desde o lançamento da Recherche os méritos do autor e seu real talento introspectivo. $O$ autor 
destaca assim que a opinião geral sobre Proust havia sido expressa, na verdade, pelo descontentamento amplo com relação à concessão do Prix Goncourt em 1919. Para Catalogne, fora preciso um longo e paciente trabalho de assimilação e compreensão, para que pouco a pouco sua obra fosse considerada importante. Este texto de 1926 mostra como eram ainda ressentidas as querelas resultantes do prêmio sete anos antes, e como elas elevaram o nome de Proust e sua obra à centralidade das discussões contemporâ neas sobre literatura.

\section{A situação pós-Grande Guerra: as redefinições das vanguardas e dos cânones}

O engajamento literário, direta ou indiretamente, havia sido quase obrigatório na França entre 1914-18, ao menos para os escritores que publicaram livros ou outros textos literários em jornais e revistas durante a Grande Guerra Mundial. Christophe Charle (2004, p. 223) destaca que a maioria dos escritores reclamava da censura que sofriam nesta conjuntura, agravada principalmente em 1917, quando jornais acusa dos de manipulações e mentiras foram inclusive suspensos pelo governo. Assim, vemos como a União Sagrada em prol da mobilização total e uníssona francesa foi avassaladora, e quase hegemônica. Com o fim do conflito bélico, porém, o debate cultural acerca da literatura e das artes sofreu novas e diversas tensões e cismas, visto que a época era sentida como momento de redefinição das concepções até então vigentes.

No mundo acadêmico, influenciado sobremaneira pela cultura germânica desde o final do século XIX, os problemas foram muitos, e diversos intelectuais até então simpatizantes da kultur alemã durante a guerra tiveram que tecer críticas e condenações aos chamados boches alemães, acusados como belicosos responsáveis pela destruição da civilização. Porém, já durante a Guerra uma tendência pacifista passou a se impor entre os intelectuais, e gradativamente foi ocupando espaços até finalmente se impor com mais força com o fim da guerra e o arrefecimento do nacionalismo.

O literato e crítico Jean Giraudoux expressou isto de maneira muito interessante em um texto de maio de 1919 publicado em Feuillets d'art, no qual saudava o escritor Marcel Proust. Ele afirma que antes de 1914, num contexto de relativa paz, contingentes maiores do publico foram iniciados na leitura. Porém, com a guerra, os escritores que não tinham interesse em engajar suas obras em favor da França no conflito bélico calaram-se. Com o fim da Guerra e a diminição da pressão pelo engajamento nacionalista dos escritores, Jean Giraudoux indica um novo período, inaugurado em 1919, que marcava para a sociedade e cultura francesas uma mudança drástica: o surgimento de novas formas de amar, de sentir e de se sociabilizar. 
Na vida literária, isto podia ser visto pelo surgimento de diversos novos livros, revistas e jornais, que exigiam novamente o direito adquirido antes da Guerra de tratarem de assuntos e temas sem um engajamento político e social total.

Paralelamente, este foi um contexto de incertezas e indefinições tanto com a produção literária, quanto com seu imediato passado e futuro. Um sintoma claro desta necessidade de discussão e redefinição da literatura contemporânea pode ser visto nas diversas tentativas de críticos e historiadores da literatura em definir a então história contemporânea da literatura e do pensamento francês. De fato, neste período foram publicados inúmeros livros que se pretendiam história, panorama ou síntese da literatura francesa.

O crítico Albert Thibaudet, comumente considerado como o mais importante do período entre guerras na França, destacou que desde pelo menos o advento da Terceira República, a produção literária francesa expressava características de um bloco, com características de uma nova tendência que para ele era justamente a consolidação do moderno. Em seu texto publicado na $N R F$ em primeiro de maio de 1920, intitulado Discussion sur le moderne, o crítico destacava que desde Charles Baudelaire e os irmãos Goncourt, havia um modernismo que não se enquandrava mais nas categorias como classicismo, romantismo, realismo ou mesmo o simbolismo, mas que na verdade atravessaria todas estas tendências. Porém, o mais importante a destacar aqui é que Thibaudet tinha claramente definida a sua missão como crítico literário defensor e divulgador desta nova literatura, afirmando inclusive que o modernismo não sobreviveria sem o apoio da crítica que, como a dele, defendia estas obras. ${ }^{7}$

Como em muitos outros espaços da sociedade francesa, o mundo da imprensa também foi cindido gravemente pela Guerra. Vimos um pouco acima que o Prix Goncourt concedido a Proust foi fator crucial para a inserção da Recherche dentro dos principais debates da vanguarda literária francesa, que se encontrava então num momento de muitas dúvidas e incertezas ao fim da guerra. Mas o fato de Proust ser o laureado foi sentido pelos seus contemporâneos como um dos sinais que apontavam para a reabertura da arte para outros caminhos que não majoritariamente o do nacionalismo demandado pela União Sagrada. Conforme Albéric Cahuet no já citado texto de 1919, a literatura francesa pós Grande Guerra buscava escapar desta obsessão dos anos precedentes que a teria imobilizado, e consequentemente também engessado a sensibilidade e a faculdade de análise dos franceses. Neste sentido, este crítico interpretava a premiação de Proust como o indicativo de um novo momento literário.

O conhecido escritor Louis Aragon, que esteve no cerne de movimentos artísticos importantes da década de 1920 como o dadaísmo e o surrealismo, chegou mesmo a acusar a

7 Este texto de Thibaudet inseriu-se emum debate como crítico Gonzague Truc, que publicou na Minerve Française (15 e 28 de fevereiro de 1920) o texto De quelques deformations de l'art littéraire moderne, acusando o modernismo. Thibaudet tomou então abertamente partido em favor da literatura moderna, acusando a crítica literária estabelecida de ser defensora exclusiva da tradição, e inimiga das vanguardas modernistas. Há também a tréplica de TRUC, De la nouveauté en littérature, La Minerve Française, Paris, 15 de junho de 1920. 
difusão e sucesso de Proust como uma estratégia ampla de progaganda e mobilização de contatos e relações por seus editores e amigos, no periódico Littérature de janeiro de 1923. Após alguns anos fechada por conta da guerra, o retorno da $N R F$ em meados de 1919 marcou, segundo Aragon, o lançamento da campanha em favor da Recherche. $\mathrm{O}$ crítico destaca assim que seus editores teriam trabalhado a opinião pública, buscando oferecer Proust como um meio termo entre Gustave Flaubert e Saint-Simon. No final, Aragon se perguntava: como é possível que não estivesse claro a todos que o realismo da Recherche se restringia apenas à pequena confraria da sociedade descrita por ele?

O fato é que as discussões em torno da obra proustiana, como por exemplo a crítica ácida feita por Aragon, cresceram vertiginosamente, desde 1919, e ao longo da década de 1920, sendo acaloradas por alguns acontecimentos como a morte de Proust no final de 1922, ou a própria publicação dos sucessivos volumes da obra até o volume derradeiro que encerrou o ciclo romancesco em 1927.

Contudo, mesmo com diversas críticas e reações, o que fica claro é que esta década foi um momento extremamente acolhedor de novas experiências artísticas nos mais diversos campos, e isto não apenas na França, mas em outras partes da Europa e alhures, como é o caso da própria Semana da Arte Moderna de 1922 em São Paulo. E isto por conta também da própria crítica literária, que se voltava com mais seriedade e atenção às novas produções e experiências. Alguns debates literários da época indicam que na verdade uma nova crítica buscava se consolidar nesta época, mais desapegada do classicismo e das restrições impostas pela tradicional literatura francesa, o que ficou bem claro com o exemplo citado acima de Thibaudet.

Algumas discussões acaloradas sobre Sainte-Beuve, considerado o crítico literário francês mais eminente no século XIX, mostram justamente isto. Daniel Halévy destacou, em Le Minerve Française de primeiro de fevereiro de 1920, que os debates decorrentes do cinquentenário da morte do crítico, principalmente as questões colocadas por Proust e Fernand Vandérem, concluíam o fracasso de Sainte-Beuve na execução de sua função. Entre as principais críticas feitas ao eminente crítico do século XIX, destacavam-se sua incapacidade de atentar para novos estilos e escritores, como seus contemporâneos Charles Baudelaires e os irmãos Goncourt. ${ }^{8}$

Os debates literários do período pós-Grande Guerra brevemente apresentados acima corroboram a afirmação de Élisabeth Parinet (2004, p. 338), segundo a qual uma das principais características deste período foi a crescente e profunda influência da literatura na vida cultural francesa, uma espécie de apogeu das letras. E nesta conjuntura, a Recherche

8 Na verdade Daniel Halévy estava críticando Proust e Vandérem, e defendende Sainte-Beuve. 
agiu por um lado tanto na consolidação literária, quanto por outro foi também beneficiada por este grande destaque literário na sociedade francesa. ${ }^{9}$

A década de 1920 também marcou um reaquecimento da imprensa e do mundo editorial como um todo. Na imprensa especializada, destacou-se então o surgimento do periódico semanal Les Nouvelles Littéraires, criado em 1922 e que dava maior espaço aos atores da vida literária para além somente de suas obras, como era a tendência das revistas. Ele foi o grande sucesso de vendas entre os periódicos literários nas décadas do entre guerras, o que pode ser atribuído à difusão popular e em massa da literatura neste contexto, que desbancava assim as revistas até então literárias e generalistas de cunho mais elitista, incapazes de responder à demanda do novo público consumidor (PARINET, 2004, p. 354). ${ }^{10}$

Embora tenha havido a abertura de novas casas de edição, revistas e jornais, o mercado editorial sofreu cada vez mais o impacto do capitalismo financeiro nesta conjuntura. Foi o momento em que grandes editoras financiadas foram criadas, inaugurando um novo momento para o mundo literário em geral. Segundo Élisabeth Parinet (2004), foi durante o entre guerras que os serviços literários de fato se profissionalizaram em especialidades nas casas de edição, principalmente nas figuras do avaliador da obra e do diretor. Por conta disto, os serviços comerciais, administrativos e publicitários passaram a influenciar muito mais as publicações.

Os responsáveis pelas casas de edições, jornais e revistas foram figuras que tiveram seu prestígio e poder elevados imensamente. Segundo François Chaubet (2006, p. 733), os novos editores se dedicaram muito para a divulgação de seus escritores, e passaram assim a decidir mais coisas nas suas vidas literárias, principalmente por meio da dependência financeira criada pelos adiantamentos e salários.

Um dos grandes exemplos disto foi Bernard Grasset, que mudou profundamente os atributos da função do editor no período pós-guerra, elevando a preocupação com as estratégias e técnicas referentes à publicidade literária a um novo patamar. Responsá vel pelo lançamento da Recherche em 1913 com a primeira edição de Du côté de chez Swann, Grasset é considerado como um dos maiores utilizadores da publicidade então para divulgação das obras dos escritores da sua casa de edição. De fato, quando o primeiro volume da Recherche, então concebida e anunciada como uma trilogia, foi publicado,

9 Um dos levantamentos bibliográficos mais exaustivos sobre a recepção da Recherche e de Proust organizado cronologicamente aponta para mais de mil e setecentas referências as mais variadas até 1939 pela imprensa francesa e pelo mercado editorial, o queindica (mas não encerra) o grande impacto e difusão que ambos tiveram desde então na cultura francesa (ALDEN, 1940).

10 A autora destaca que o periódico Nouvelles Littéraires ajudou na nova midiatização das personalidades literárias, utilizando muitas fotos e imagens. O periódico era sustentando pela editora Larousse. Segundo Charle, ele alcançou 150 mil leitores em 1926, oferecendo assim conteúdoliterário ao novo público de massa mais cultivado, em um formato que unia a apresentação de umjornal e a periodicidade semanal de uma revista por um baixo custo. Para Charle, o sucesso deste periódico se deveu também muito à sua atenção aos escritores consagrados no período pós guerra, como é o caso de Marcel Proust (CHARLE, 2004, p. 328-330). Chaubet considera o período pós guerra como a inauguração de uma nova era das massas cultivadas (CHAUBET, 2006, p. 737-738). 
apareceram em alguns periódicos artigos e notícias divulgando e explicando a obra, isto muito por conta das relações de Proust e as estratégias publicitárias de Grasset. ${ }^{11} \mathrm{E}$, embora este primeiro volume tenha alcançado uma difusão restrita até 1919, é inegável que conseguiu algum sucesso muito graças às amizades, relações e talentos tanto de Grasset quanto de Proust. Tanto que levantou o interesse da $N R F$ e Gallimard, os quais obstinadamente buscaram desde então incluir Proust entre seus escritores.

Proust havia já tentado, e fracassado, publicar a Recherche pela $N R F$ antes de fazê-lo por Grasset. A defesa da arte pela arte, o vanguardismo, o ecletismo, entre outros motivos, seduziam Proust, e de fato, aproximavam-no muito de outros escritores da $N R F$. Sua aproximação e ingresso nas edições de Gallimard acabaram por torná-lo, ao lado de escritores como André Gide e Paul Valéry, uma das principais bandeiras da revista que retornou em 1919 reafirmando seu compromisso com uma arte liberta de qualquer restrição ideológica e utilitarista (ou seja, contra alguns dos princípios que a Guerra havia legado à produção literária). Foi sem dúvida a partir deste momento que Proust começou, ainda que de maneira tímida, a ser considerado um dos mestres tardios das novas gerações do século $\mathrm{XX}$.

Este período entre guerras possibilitou a elevação da $N R F$ ao mais alto degrau da vanguarda literária francesa, ocupando o lugar que outras revistas como Mercure de France e Ermitage, por exemplo, tinham buscado antes da Guerra. No mesmo caminho da especialização destacada acima, em 1919 a revista separou-se da casa de edição, criando assim a sociedade anônima Éditions Gallimard. Para Parinet, a consolidação do comitê de leitura e avaliação criado pela editora foi então decisiva para sua afirmação como a editora mais importante da vanguarda intelectual e artística desde então. Estes consultores multiplicavam as possibilidades de contato com autores, dadas suas relações pessoais, e assim ampliavam as redes de relações entre editores, críticos e escritores. A defesa da autonomia literária e a abertura às inovações modernistas possibilitaram uma base, embora bem indefinida, para um sentimento que unia os escritores que lançavam artigos e livros tanto pela $N R F$, quanto pela editora Gallimard, que embora legalmente separadas, acabavam se fortalecendo mutuamente.

É extremamente interessante, portanto, notar como a obra de Proust gravitou, mesmo que de maneira muito efêmera, entre os dois editores provavelmente considerados como os mais importantes no que concerne à produção literária francesa do período entre guerras: Gaston Gallimard e Bernard Grasset. Editores audaciosos e inovadores que, segundo Élisabeth Parinet (2004, p.338-353), tinham em comum o desejo de dominar a cena

11 Podemos inclusive ver a difusão aí de uma fórmula da obra, artefato publicitário criado e consentido provavelmente pelo autor e editor, e que veiculava uma determinada leitura da obra como anunciação dela ao público. Por exemplo, o jornal Gil Blas de 9 de novembro 1913 repete a fórmula provavelmente veiculada por Grasset e/ou Prou st também em outros jornais, de que a Recherche era um estudo elegante e irônico de alguns meios mundanos e a evocação de paisagens e lembranças passadas. 
intelectual da época, o que não deixa de ser importante quando consideramos que disputaram o escritor que, ao longo do século $\mathrm{XX}$, se consolidou como o principal romancista daquela conjuntura.

\section{A crítica como ritual de iniciaçãoliterária}

A produção literária modernista dependeu muito da intermediação e iniciação possíveis através da crítica e comentários em geral sobre obras muitas vezes consideradas extremamente difíceis e inacessíveis ao público. Quando nos deparamos com os primeiros comentários, leituras e interpretações da obra proustiana, podemos ver claramente como uma produção vanguardista pôde causar estranhamento e dúvidas em leitores que poderíamos chamar de inadvertidos, e necessitou de diversos processos, e de tempo, para ser assimilada.

Conforme Luiz Costa Lima (1980, p. 133), a mímeses da modernidade exigiu que o leitor fosse iniciado, para então se tornar uma espécie de eleito espiritualizado e apto. A importância do controle deste processo de iniciação fez com que os processos de leitura e apreensão dos sentidos das produções literárias fossem inclusive constantemente temas de artigos e debates, em intensas disputas e querelas. Pierre Loewel, por exemplo, no jornal L'Eclair de 19 de março de 1924 buscou analisar alguns dos impasses entre os leitores de Proust e sua obra. $O$ referido artigo é um breve estudo do primeiro volume póstumo da Recherche que acabava de ser publicado, La Prisonnière, e louvava a continuação do romance que logo viria a público na íntegra. Loewel acreditava que o principal problema advinha dos novos leitores que a Recherche adquirira desde o sucesso repentino após 1919 e o Prix Goncourt, os quais supostamente não tinham lido o primiero volume de 1913. Logo, a incompreensão adviria da não leitura do romance desde seu princípio. Por fim, mas provavelmente o trecho mais pertinente da sua crítica em L'Eclair, Pierre Loewel destacava a necessidade de uma lenta aclimatação do leitor da Recherche, para que assim o público efetivamente conseguisse acompanhar a obra proustiana.

Outros críticos e conhecedores da literatura propuseram inclusive métodos para a leitura dos livros que compõem a Recherche, mostrando assim a demanda não apenas por interpretações e leituras que auxiliassem na difusão destas obras que causavam 
estranhamento no público, mas inclusive fórmulas e métodos para ter acesso ao então eminente escritor. ${ }^{12}$

Outra documentação que deflagra a função da crítica como intermediária social e cultural são os comentários muitas vezes publicados na imprensa sobre livros e artigos que tomaram Proust e sua obra como objetos e temas, prática que se tornava recorrente na produção crítica literária da década de 1920, dado o sucesso da obra proustiana. Pois nestes textos são avaliados as vantagens e erros das interpretações e leituras feitas da obra proustiana por diversos comentadores, e inclusive por eminências da crítica e história literária da época.

Fernand Vandérem, na Revue de France de 15 agosto de 1925, saudava então o primeiro livro dedicado na íntegra ao estudo de Proust e sua obra, de autoria de Léon Pierre-Quint. Vandérem inicia seu comentário dizendo que poucos romancistas suscitaram tantos estudos, artigos e comentários naquela época como Proust, o que fazia da exegese proustiana um caminho de entrada para jovens escritores na literatura. Contudo, destaca Vandérem, o livro Marcel Proust, sa vie, son oeuvre, de autoria de Pierre-Quint, seria diferente porque finalmente fornecia um estudo e uma interpretação da Recherche não exclusivamente direcionada para os iniciados. Fernand Vandérem exagera ao afirmar que salvo um ou outro comentador, a crítica não compreendia absolutamente nada da importância da obra de Proust, pois sua obra já era considerada um acontecimento literário que marcava época. Porém, é interessante atentar para o elogio que Vandérem faz da obra de Pierre-Quint, como propaganda para divulgar e popularizar a Recherche.

Por fim, o crítico literário da Revue de France, mais uma vez de forma exagerada, afirma que o sucesso e glória de Proust eram frutos unicamente do esforço dos diversos defensores da obra, como o próprio Vandérem. Contudo, este crítico nos transmite aqui esta questão fundamental, pela qual vemos a importância das relações e laços sociais nos processos de divulgação literária.

A extrema floração das revistas culturais e literárias como fenômeno do final do século XIX e início do XX mostra o espaço de potencial expansão deste crescente ramo do campo literário constituído pelas diversas formas de produção midiática entre leitor e escritor. Segundo Charle (2004, p. 169-200), o florescimento das pequenas revistas literárias como fenômeno do final do século XIX demonstrava o descontentamento com os antigos mediadores, ou seja, uma espécie de demanda intelectual por novas gerações mais articuladas com as novas paisagens literárias.

Para François Chaubet (2006, p. 723-772), a palavra do escritor ao longo do século XX se sustentou pela existência de um tecido de mediações, o que podemos ver pelo 
desenvolvimento de um mercado cultural que ajudava a garantir a consolidação do sucesso da literatura. Retornando ao texto citado de Albert Thibaudet de maio 1920 pela NRF, Discussion sur le moderne, onde ele não só defende o modernismo literário mas afirma que esta é uma das tarefas da crítica, podemos suspeitar que o estabelecimento destes críticos mais atentos às produções inovadoras estava intimamente ligado ao próprio sucesso das obras modenistas. Ou seja, a afirmação de uma nova paisagem literária modernista no período pós guerra se fazia apoiando e apoiado na própria consolidação de uma nova crítica mais atenta e interessa da pelas produções literárias inovadoras.

Conforme Christophe Charle (2004, p. 327-351), espaços na mídia como a crônica e a crítica literária serviram como espécies de filtros entre a oferta cultural e o público em potencial, e tornaram-se instâncias de poder à medida que o periódico ganhava audiência. Este foi o caso da $N R F$ (intimamente ligada às edições Gallimard) desde o fim da Grande Guerra, periódico onde Thibaudet consolidava-se então como um dos principais críticos literários da época.

A produção literária modernista de fato foi muito dependente da exegese difundida pelas mais variadas formas, em jornais, revistas e livros, pois sem estas interpretações e sentidos ela corria muitas vezes o risco de cair no desconhecimento ou esquecimento. Isto é reforçado no caso da produção modernista tendo em conta que um dos princípios básicos desta é o rompimento com padrões estéticos estabelecidos de apreensão da realidade.

Isto nos leva a considerar a obra de arte como não estando fechada, e também a considerá-la como algo mais que o resultado da pura intenção criadora do autor. Conforme Peter Gay (2009, p. 98-110), as trajetórias e obras modernistas não resultam da vida isolada dos artistas, e dependem sempre de determinados intermediários que trabalham consciente e inconscientemente na sua difusão. Gay denomina inclusive de pedagogos estes divulgadores que tinham como principal função habituar o público às criações que muitas vezes, de tão originais e inovadoras, acabavam sendo chocantes e inacessíveis.

De fato, conforme François Chaubet (2006, p. 734-740), neste contexto da década de 1920, os escritores e editores acabaram buscando múltiplas maneiras pelas quais suas obras pudessem ser intermediadas e oferecidas ao público, o que tornou a mídia praticamente um suporte incontornável da atividade literária. Mas, se por um lado, a intermediação auxiliava a divulgação de uma obra, tirava também o suposto poder hegemônico que o autor possuía dela, sobretudo no incerto e suscetível processo de recepção.

Assim, vemos a importância de uma gama de agentes os quais favoreceram a divulgação e sucesso de inúmeras obras artísticas modernistas, como empresários, comerciantes, produtores de peças, críticos de arte, editores, proprietários, redatores e diretores de jornais e revistas. De fato, cada campo artístico passara a contar com suas 
próprias categorias de profissionais especializados e habilitados que intervinham na divulgação das obras, na atribuição de sentidos e interpretações:

\begin{abstract}
Sem essa assistência, o modernismo provavelmente teria permanecido como campo restrito de alguns amadores excêntricos e endinheirados, em vez de se avolumar como uma avalanche irresistível que traria transformações fundamentais no gosto estético. Outra poderosa instituição pedagógica nas artes, a crítica, voltada mais para os consumidores do que para os produtores de cultura, desenvolveu uma relação com as artes mais ambígua do que com os negociantes e os empresários culturais (GAY, 2009, p. 103).
\end{abstract}

Segundo Peter Gay, portanto, a crítica estava mais voltada para os consumidores, numa época que os periódicos em geral tinham grande circulação.

Porém, não devemos esquecer que a liberalização do mundo editorial e da imprensa pela Terceira República veio acompanhada de uma aguda necessidade de enquadramento da leitura. Segundo Gisèle Sapiro (2009, p. 423-425), a leitura esteve no centro das preocupações não só da república, como do debate público em geral, pois era o principal instrumento de educação nesta conjuntura, portanto um veículo fundamental na formação dos cidadãos franceses.

Podemos ver como exemplo o periódico da década de 1920 intitulado Romans Revue: guide de lecture, mais tarde renomeado para Revue de Lectures. A parte dedicada à recente produção literária nesta revista era então inusitadamente apresentada como: $I$ - Romances maus, perigosos e inúteis para leitores em geral; II - Romances que podem, através de razões proporcionais, permitir a leitura a grandes pessoas suficientemente advertidas; III - Romances que podemos, malgrado o fundo ou certas páginas, recomendar a leitura para grandes pessoas em razão do beneficio ou do lazer sem perigo que eles procuram; IV - Romances inofensivos e recomendados para os leitores de idade conveniente ou sabiamente formadas; e $V$ - Romances destinados a toda juventude, às jovens garotas e genericamente à todas as categorias de leitores. ${ }^{13}$

Vemos aqui claramente uma intenção em classificar as produções literárias conforme o risco que ofereciam ao público leitor, este também classificado indiretamente e relacionado aos tipos de livro que poderia ter acesso.

13 Livre tradução do original emfrancês. O artigo de Charles Bourdon de 15 de janeiro de 1920 enquadrava os livros de Proust Du côté de chez Swann, À l'ombre des jeunes filles em fleurs e Pastiches et Mélanges no não tão inocente e inofensivo segundo nível. 
O que fica cada vez mais patente é que havia nesta conjuntura da vida de Marcel Proust e de publicação da Recherche íntimas relações e ligações entre a consolidação do que podemos denominar de realismo literário modernista e a escrita da crítica literária e imprensa em geral. De fato, muitos comentadores apresentaram a obra proustiana como memórias de uma época, e não um romance: ela era apresentada, a partir desta leitura, como um tipo de jornal íntimo, porém publicado, escrito por um homem que desenhava muito bem as tendências e atualidades de uma época.

Em uma crítica um tanto mordaz à obra de Proust na Revue Universelle de 15 de agosto de 1925, René Johannet colocava em dúvida se de fato sua obra seria um romance, concluindo que na verdade se tratavam antes de memórias de um homem doente, mundano e solitário. Johannet evoca uma suposta carta que Proust teria lhe escrito, na qual disse que seu desejo era dar uma ideia exata do que se chamava então o espírito fin-de-siècle XIX, para concluir sua crítica afirmando que para isso existiam já as memórias, a verdaderia tradição à qual se deveria ligar Proust.

Segundo André Belo (2008, p. 93), era comum que editores e autores transitassem entre os periódicos e os livros neste contexto do final do século XIX, quando o livro até então hegemônico como veículo da comunicação escrita fora ultrapassado em números de publicação e distribuição por impressos mais baratos e acessíveis como os jornais, revistas e brochuras.

Estes espaços de intermediação, de trocas, assistências e disputas entre a literatura, a imprensa e o público apontam para as relações entre uma cultura literária mais elitizada e sua popularização e massificação. ${ }^{14} \mathrm{E}$ o próprio escritor Marcel Proust esteve atento a estas relações, buscando outras formas de interceder na recepção de sua obra, como entrevistas, comentários e "esclarecimentos".15

Porém, na prática, os livros publicados que compunham a Recherche eram desencorajadores para grande parte do público, e isto por inúmeras razões destacadas pela própria recepção da obra. Além da considerada dificuldade em ler a obra e entender as trajetórias ali relatadas, o tamanho dela se impunha aos leitores, o que fora reforçado pela própria publicação que se estendera por quatorze anos. Muitos leitores se queixaram também do próprio formato compacto, ou seja, da forma tipográfica cerrada que acabava por aglutinar uma quantidade enorme de texto ao longo das páginas dos livros. Mas de qualquer forma, a obra proustiana como acontecimento literário é um excelente exemplo

14 Segundo Franco Moretti (2007, p.29), é inegável a existência das relações entre a literatura de massa e a chamada alta cultura literária.

15 Proust insistiu muito, por exemplo, na negação de algumas críticas que recebia como sua aparente falta de composição, e sua escala de descrição minuciosa e microscópica. De fato, o autor da Recherche advertiu ainda em vida seus leitores, que viram mais tarde a confirmação de que a obra havia sido atenta e profundamente composta, além de apresentar questões abrangentes e essenciais, e não apenas curiosas minúcias da vida durante a Belle Epoque. 
para compreender algumas das complexas relações que se estabeleceram na França entre literatura, imprensa e mercado editorial, principalmente a partir do final do século XIX.

\section{Referências}

ALDEN, Douglas William. Marcel Proust and hist French Critics. Los Angeles: Lymanhouse, 1940.

ARAGON, Louis. Je m'acharne sur un mort. Littérature, Paris, 1 jan. 1923. p. 23-24.

BELO, André. História \& Livro e Leitura. Belo Horizonte: Autêntica, 2008.

BOURDIEU, Pierre. As regras da arte: gênese e estrutura do campo literário. Tradução de Maria Lucia Machado. São Paulo: Companhia das letras, 2005.

BOURDON, Charles. Les Romans. Revue des lectures, Paris, 15 de janeiro de 1920. p 23-29.

CAHUET, Albéric. Prix Littéraires. Illustration, Paris, 27 dez. 1919. p. 541-542.

CATALOGNE, Gérard de. Marcel Proust et ses critiques. Revue le Capitole, Paris, 1926. p. 171201.

CHARLE, Christophe. Le siècle de la Presse (1830-1939). Paris: Seuil, 2004.

CHAUBET, François. Les relais de l'écrivain au XX' siècle. In. BERTHIER, Patrick; JARRETY, Michel. (Dir.) Histoire de la France littéraire. Modernité. XIX $\mathrm{XX}^{\mathrm{e}} \mathrm{XX}^{\mathrm{e}}$ siècle. Paris: Presses Universitaires de France, 2006. t.3, p. 723-772.

CLAIRET, Georges. Le Prix Goncourt à Marcel Proust. Le Journal du Peuple, Paris, 11 dez. 1919. COMPAGNON, Antoine. La Troisième République des Lettres, de Flaubert à Proust. Paris: Seuil, 1983.

DANIEL-ROPS, Henri. Proust et Quatre Critiques. Cahiers du mois, Paris, jun. 1925. p. 70-71.

DERIVE. A propos du prix Goncourt. Comoedia, Paris, 3 jun. 1920.

GAY, PETER. Modernismo: o fascínio da heresia: de Baudelaire à Beckett e mais um pouco. Tradução de Denise Bottmann. São Paulo: Companhia das Letras, 2009. 


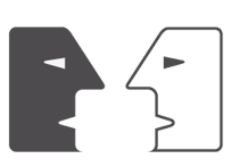

ANTÍTESES

GIRAUDOUX, Jean. Du côté de chez Marcel Proust. Chronique Littéraire. Feuillets d'art, Paris, maio 1919.

GRENIER, Jean-Charles. Proust ou: Du feu d'artifice au film documentaire. Les directions présentes de la littérature. Où nous en sommes. La vie des lettres et des arts, Paris, outubro de 1923. p. 75-79.

_. Proust (fin), Giraudoux, Morand. Les directions présentes de la littérature. Où nous en sommes. La vie des lettres et des arts, Paris, dez. 1923. p. 63-69.

GSELL, Paul. Au Jour le Jour. Nos Échos. La Démocratie Nouvelle, Paris, 11 dez. 1919.

HALEVY, Daniel. Sur la Critique de Sainte-Beuve. Le Minerve Française, Paris, 1 fev. 1920.

JACQUEMARIE, Madeleine Clemenceau. A propos de La Prisonnière. L'Écho National, Paris, 16 mar. 1924.

JOHANNET, René. Les prédécesseurs de Marcel Proust. Les Lettres. Revue Universelle, Paris, 15 ago. 1925.

KARAKATSOULIS, Anne. Revue des Deux Mondes. In: JULLIARD, Jacques; WINOCK, Michel (Dir.). Dictionnaire des intellectuels français. Les personnes, les lieux, les moments. Nouvelle Edition. Paris: Seuil, 2009. p. 1188-1189.

Le prix Goncourt. L'Opinion, Paris, 13 dez. 1919.

Le Prix Goncourt est décerné aujourd'hui. Bonsoir, Paris, 11 dez. 1919.

LEROY, Géraldi; BERTRAND-SABIANI, Julie. La vie littéraire à la Belle Époque. Paris: Presses Universitaires de France, 1998.

LES UNS. Les Lettres: Un roman de Marcel Proust. Gil Blas, 9 nov. 1913.

LIMA, Luiz Costa. Mímeses e modernidade. Formas das Sombras. Rio de Janeiro: Graal, 1980.

LOEWEL, Pierre. La Prisonnière. L'Eclair, Paris, 19 mar. 1924.

MOLLIER, Jean-Yves. A leitura e seu público no mundo contemporâneo. Ensaios sobre História Cultural. Tradução de Elisa Nazarin. Belo Horizonte: Autêntica, 2008.

MORETTI, Franco. Signos e estilos da modernidade. Ensaios sobre a sociologia das formas literárias. Tradução de Maria Beatriz de Medina. Rio de Janeiro: Civilização Brasileira, 2007. 
NIKEL, Séverin. Mercure de France. In. JULLIARD, Jacques; WINOCK, Michel (Dir.). Dictionnaire des intellectuels français. Les personnes, les lieux, les moments. Nouvelle Edition. Paris: Seuil, 2009, p. 945-946.

Notre Carnet. Pays, Paris, 12 de dezembro de 1919.

PARINET, Élisabeth. Une histoire de l'édition à l'époque contemporaine. XIX ${ }^{\mathrm{e}} \mathrm{XX}{ }^{\mathrm{e}}$ siècle. Paris: Seuil, 2004.

PROUST, Marcel. À la recherche du temps perdu. Tome I: Du côté de chez Swann. Paris: Bernard Grasset, 1914.

À la recherche du temps perdu. À l'ombre des jeunes filles en fleurs. Paris: Nouvelle Revue Française, 1918. t. 2.

À la recherche du temps perdu. Le côté de Guermantes I. Paris: Nouvelle Revue Française, 1920. t. 3.

À la recherche du temps perdu. Le côté de Guermantes II. Sodome et Gomorrhe I. Paris: Nouvelle Revue Française, 1921. t. 4.

_._._. À la recherche du temps perdu. Sodome et Gomorrhe II. Paris: Nouvelle Revue Française, 1922. t. 5 .

À la recherche du temps perdu. La Prisonnière (Sodome et Gomorrhe III). Paris: Nouvelle Revue Française, 1923. t. 6.

_. _ _ . À la recherche du temps perdu. Albertine disparue. Paris: Nouvelle Revue Française, 1925. t. 7.

. À la recherche du temps perdu. Le temps retrouvé (2 vols.). Paris: Nouvelle Revue Française, 1927. t. 8.

ROSNY, Joseph-Henri. Le Tréteau des Lettres. L'Opinion Littéraire: Le cas de M. Marcel Proust. Comoedia, Paris, 23 dez. 1919.

SAPIRO, Gisèle. La responsabilité de l'écrivain. Littérature, droit et morale em France (XIX ${ }^{\mathrm{e}}$ XX' siècle). Paris: Seuil, 2011.

SCHWARTZ, Vanessa. O espectador cinematográfico antes do aparato do cinema: o gosto do público pela realidade na Paris fim-de-século. In: CHARNEY, Leo; SCHWARTZ, Vanessa (Org.). O cinema e a invenção da vida moderna. São Paulo: Cosac \& Naify, 2001. p. 411-440. 
SIMONIN, Anne. Prix Littéraires. In: JULLIARD, Jacques; WINOCK, Michel (Dir.). Dictionnaire des intellectuels français. Les personnes, les lieux, les moments. Nouvelle Edition. Paris: Seuil, 2009. p.1132-1134.

THÉRENTY, Marie-Ėve. La Littérature au quotidien. Poétiques journalistiques au XX $\mathrm{X}^{\mathrm{e}}$ siècle. Paris: Seuil, 2007.

THIBAUDET, Albert. Réflexions sur la Littérature: Discussion sur le moderne. Nouvelle Revue Française, Paris, maio de 1920. p. 727-739.

TRUC, Gonzague. De la nouveauté en littérature. La Minerve Française, Paris, 15 jun. 1920. . De quelques deformations de l'art littéraire moderne. La Minerve Française, Paris, 15 e 28 fev. 1920.

VANDÉREM, Fernand. La Femme de paille e Marcel Proust (de Léon Pierre-Quint). Les lettres e la vie. Revue de France, Paris, 15 ago. 1925.

_ _ _ _ _ . Les lettres et la vie. La Revue de France, Paris, 15 jun. 1922.

WEBER, Eugen. França fin-de-siècle. Tradução de Rosaura Eichenberg. São Paulo: Companhia das Letras, 1989.

WINOCK, Michel. O século dos intelectuais. Tradução de Eloá Jacobina. Rio de Janeiro: Bertrand Brasil, 2002.

Recebido em 08/03/2017

Aprovado em 29/06/2017 